\title{
Vooronderzoek intergenerationele inkomensmobiliteit in Nederland
}

Citation for published version (APA):

van den Brakel, M., Büchner, C. I. R., Cörvers, F., Moonen, L., Traag, T., \& van der Velden, R. K. W. (2010). Vooronderzoek intergenerationele inkomensmobiliteit in Nederland. ROA. ROA Technical Reports No. 004 https://doi.org/10.26481/umarot.2010004

Document status and date:

Published: 01/01/2010

DOI:

10.26481/umarot.2010004

Document Version:

Publisher's PDF, also known as Version of record

\section{Please check the document version of this publication:}

- A submitted manuscript is the version of the article upon submission and before peer-review. There can be important differences between the submitted version and the official published version of record.

People interested in the research are advised to contact the author for the final version of the publication, or visit the DOI to the publisher's website.

- The final author version and the galley proof are versions of the publication after peer review.

- The final published version features the final layout of the paper including the volume, issue and page numbers.

Link to publication

\footnotetext{
General rights rights.

- You may freely distribute the URL identifying the publication in the public portal. please follow below link for the End User Agreement:

www.umlib.nl/taverne-license

Take down policy

If you believe that this document breaches copyright please contact us at:

repository@maastrichtuniversity.nl

providing details and we will investigate your claim.
}

Copyright and moral rights for the publications made accessible in the public portal are retained by the authors and/or other copyright owners and it is a condition of accessing publications that users recognise and abide by the legal requirements associated with these

- Users may download and print one copy of any publication from the public portal for the purpose of private study or research.

- You may not further distribute the material or use it for any profit-making activity or commercial gain

If the publication is distributed under the terms of Article $25 \mathrm{fa}$ of the Dutch Copyright Act, indicated by the "Taverne" license above, 


\section{Vooronderzoek intergenerationele inkomensmobiliteit in Nederland}

Marion van den Brakel (CBS)

Charlotte Büchner (ROA)

Frank Cörvers (ROA)

Linda Moonen (CBS)

Tanja Traag (CBS)

Rolf van der Velden (ROA)

Centraal Bureau voor de Statistiek

\section{ROA Technical Report}

ROA-TR-2010/4

Research Centre for Education and the Labour Market

Maastricht University

P.O. Box 616, 6200 MD Maastricht, The Netherlands

$\mathrm{T}+31433883647 \mathrm{~F}+31433884914$

secretary-roa-sbe@maastrichtuniversity.nl

www.roa.nl 


\title{
Vooronderzoek intergenerationele inkomensmobiliteit in Nederland
}

\author{
Marion van den Brakel (CBS) \\ Charlotte Büchner (ROA) \\ Frank Cörvers (ROA) \\ Linda Moonen (CBS) \\ Tanja Traag (CBS) \\ Rolf van der Velden (ROA)
}

ROA-TR-2010/4

mei 2010

Research Centre for Education and the Labour Market

Maastricht University

P.O. Box 616, 6200 MD Maastricht, The Netherlands

$\mathrm{T}+31433883647 \mathrm{~F}+31433884914$

secretary-roa-sbe@maastrichtuniversity.nl

www.roa.nl 


\section{Voorwoord}

Dit vooronderzoek is tot stand gekomen op verzoek van het Ministerie van Sociale Zaken en Werkgelegenheid (SZW). Het Ministerie van SZW heeft met het oog op de beleidsontwikkeling op lange termijn behoefte aan meer inzicht in de mate van intergenerationele mobiliteit in Nederland. Intergenerationele mobiliteit is één van de zwaartepunten binnen het thema Sociale samenhang van de Strategische Kennisagenda van SZW. Het vooronderzoek is uitgevoerd door onderzoekers van het CBS en het ROA in het kader van de samenwerkingsrelatie tussen beide instituten. 



\section{Inleiding}

Het Ministerie van Sociale Zaken en Werkgelegenheid heeft het ROA gevraagd om een haalbaarheidsonderzoek uit te voeren naar de kwantificering van de inkomensmobiliteit tussen generaties in Nederland en de kwantificering van de factoren die deze mobiliteit beïnvloeden. Het ROA heeft dit haalbaarheidsonderzoek uitgevoerd in samenwerking met het CBS. Dit rapport vormt hiervan het verslag.

Een te geringe inkomensmobiliteit tussen generaties kan als ongewenst worden beschouwd omdat dan achterstanden van ouder op kind in sterke mate worden doorgegeven. Het is voor ouders met een hoog inkomen gemakkelijker dan voor ouders met een laag inkomen om te investeren in de toekomst van hun kinderen, bijvoorbeeld door de kosten van goed onderwijs te financieren. De vraag is hoe belangrijk deze factor is voor Nederland, waar de toegankelijkheid van het onderwijs immers goed is en de kwaliteitsverschillen tussen onderwijsinstellingen (denk aan universiteiten) niet groot zijn.

Voor het schatten van de intergenerationele inkomensmobiliteit is het van belang om te beschikken over inkomensgegevens van zowel de ouders als de kinderen op vergelijkbare leeftijd. Daarnaast is het van belang om een beeld te krijgen van de mechanismen waarlangs overdracht van inkomen plaatsvindt. Is er sprake van een directe overdracht van economische hulpbronnen of vindt de overdracht plaats via andere mechanismen, zoals de aanwezigheid van menselijk kapitaal in het gezin van herkomst, de aanwezigheid van sociale hulpbronnen en cultureel kapitaal in het gezin, gezondheid et cetera? Elk van deze mechanismen kan een intermediaire rol vervullen in de relatie tussen inkomen van de ouders enerzijds en inkomen van de kinderen anderzijds. Om een voorbeeld te geven: het inkomen van de ouders is sterk gecorreleerd aan het opleidingsniveau van deze ouders. Het opleidingsniveau van de ouders is op zijn beurt de beste voorspeller van het opleidingsniveau van de kinderen en die bepaalt vervolgens weer het inkomen. Naast de diverse hulpbronnen in het gezin (menselijk kapitaal, economisch kapitaal, sociaal kapitaal, cultureel kapitaal), kan ook erfelijke overdracht van potentiële vaardigheden zoals IQ een rol spelen.

Er zijn twee lijnen van onderzoek die van belang zijn voor dit onderzoeksthema. In het sociale stratificatieonderzoek is veel aandacht besteed aan de relatie tussen sociale status van de ouders en de sociale status van de kinderen. Dit type onderzoek richt zich met name op de intergenerationele sociale mobiliteit, en de mate waarin deze varieert tussen landen en in de tijd. Hierbij wordt onder meer specifiek gekeken naar de intermediaire mechanismen zoals de rol van cultureel kapitaal van de ouders. Ofschoon hierbij ook gekeken wordt naar het effect van financiële hulpbronnen, beperkt het onderzoek zich meestal tot de relatie tussen inkomen van de ouders en bereikte opleidingsniveau of bereikte sociale status van de kinderen. $\mathrm{Er}$ is daarentegen veel minder bekend over de inkomensmobiliteit waarbij het inkomen voor zowel ouders als kinderen op eenzelfde leeftijd gemeten is. Zo wordt in de OECD-studie van Going for Growth 2010 met name gekeken naar de invloed van het opleidingsniveau van de vader op de prestaties en het inkomen van de kinderen. Nederland lijkt ten opzichte van andere landen van de EU of de OECD hooguit gemiddeld te scoren wat betreft de mate van mobiliteit tussen generaties.

De tweede lijn van onderzoek betreft het economisch onderzoek naar inkomensmobiliteit. Een schatting door Cörvers en De Loo (2001) op basis van het Inkomens Panel Onderzoek (IPO) van het CBS geeft eveneens aan 
dat de inkomensmobiliteit tussen generaties gemiddeld is in vergelijking met andere landen. Tevens wordt er in hun onderzoek ingegaan op de beperkingen van de door hen gebruikte data en methodiek. ${ }^{1}$ Een belangrijke beperking in hun onderzoek is dat er behalve de inkomenspositie van de ouders geen zicht is op alle andere factoren die de intergenerationele transmissie van inkomen kunnen bewerkstelligen. In meer recent CBSonderzoek door Van den Brakel en Moonen (2009) is voor de intergenerationele analyses eveneens gebruik gemaakt van het IPO. Het IPO is echter een relatief klein panel (ca. 75.000 huishoudens), waardoor het weinig perspectief biedt op koppelingen met andere 'rijkere' databestanden die ook een steekproefkarakter hebben. Daardoor blijft het onduidelijk welke mechanismen bijdragen aan intergenerationele inkomensmobiliteit.

We kunnen derhalve concluderen dat beide lijnen van onderzoek hun beperkingen hebben. Het stratificatieonderzoek is sterk in het beschrijven van de mechanismen maar het ontbreekt daar aan directe metingen van de inkomensmobiliteit. In het economisch onderzoek daarentegen wordt de intergenerationele inkomensmobiliteit doorgaans wel vastgesteld maar is er minder zicht op de mechanismen waarlangs deze overdracht plaatsvindt.

In dit vooronderzoek wordt nagegaan wat de mogelijkheden zijn om de analyses over intergenerationele inkomensmobiliteit met veel rijkere databestanden uit te voeren dan met het IPO. Daardoor zouden ook de hierboven genoemde factoren zoals de verschillende soorten hulpbronnen in het ouderlijk milieu moeten worden meegenomen in de analyse. Er wordt aansluiting gezocht bij het project Langetermijneffecten van Onderwijs van het CBS. In dit project worden de effecten van onderwijs op verschillende domeinen van de levensloop in kaart gebracht. Daarbij wordt gebruik gemaakt van een koppeling tussen de schoolloopbaanonderzoeken en de registerdata van het Sociaal Statistisch Bestand (SSB). In een recent onderzoek door Büchner, Smits en Van der Velden (2008) wordt bijvoorbeeld een analyse gemaakt van de langetermijneffecten van het onderwijs op de kans op werk en het inkomen van dertigers. De studie bouwt voort op een eerdere analyse van Traag et al. (2006). Daarin is nagegaan wat het effect is van opleiding en andere persoonskenmerken op het arbeidsmarktsucces van mensen die op dat moment 33 jaar waren. Uit deze analyse bleek dat nog geen 20 procent van de loonverschillen tussen dertigers verklaard kon worden door hun opleidingsniveau, hun opleidingsrichting of hun cognitieve vaardigheden. Ook de effecten van sociale herkomst bleken gering. In het onderzoek is echter geen rekening gehouden met het inkomen van de ouders op vergelijkbare leeftijd.

Om tot een goede schatting te komen van de intergenerationele inkomensmobiliteit is het van belang om de bestaande schoolloopbaanonderzoeken uit te breiden met inkomensgegevens van de ouders. In dit vooronderzoek wordt nagegaan welke inkomensdata kansrijk zijn voor de koppeling met de schoolloopbaanonderzoeken.

In de volgende paragraaf worden de voor- en nadelen van de verschillende inkomensbestanden van het CBS nagegaan, en wordt aangegeven welke bestanden de voorkeur hebben gegeven de onderzoeksvraagstelling. In paragraaf 3 wordt de vraag beantwoord welke mogelijkheden de schoolloopbaanonderzoeken van het CBS bieden om het onderzoek naar intergenerationele inkomensmobiliteit uit te voeren. In de laatste en concluderende paragraaf wordt aangegeven of het onderzoek uitvoerbaar is, welke beperkingen daarbij gelden, welke

1. Zie voor de reactie van Plug op het artikel, en hun naschrift: http://www.roa.unimaas.nl/cv/Coervers/reserearchtopics.htm. Zie voor andere analyses met de IPO-data ook Cörvers (2000abc, 2001, 2004). 
mogelijkheden de databestanden van het CBS bieden om tot een internationale wetenschappelijke publicatie te komen, en wat de termijn is waarbinnen dit onderzoek kan worden afgerond, en wat de bijbehorende kosten zijn.

\section{Inkomensgegevens}

Om uitspraken te kunnen doen over inkomensmobiliteit tussen generaties zijn inkomensgegevens nodig van beide generaties op vergelijkbare levensmomenten. Voor het schatten van de 'earnings elasticity' kan gebruik gemaakt worden van het IPO. Het IPO beschikt namelijk over de precieze arbeidsinkomsten, terwijl deze uit andere uit inkomensbestanden alleen bij benadering bekend zijn. Een beperking van het IPO is echter dat deze geen inzicht kan bieden in achterliggende factoren die de inkomensmobiliteit tussen generaties kunnen beïnvloeden. Dit inzicht kan echter wel verkregen worden door koppeling van onderwijscohorten met inkomensgegevens. Vanwege de geringe steekproefomvang is het IPO (1,6 procent van de bevolking) ${ }^{2}$ hiervoor ongeschikt en moet er een beroep worden gedaan op andere databronnen. Het CBS beschikt over twee andere databronnen waar de inkomensgegevens van de respondenten van de onderwijscohorten en hun ouders uit gehaald kunnen worden, namelijk de bestanden van het Regionaal Inkomensonderzoek (RIO) en de zogenaamde Fibasebestanden.

Hieronder volgt eerst een korte beschrijving van het IPO, het RIO en de Fibase, gevolgd door een beknopte uiteenzetting van de verschillende inkomensbegrippen die in deze bestanden voorhanden zijn. Daarna worden de voor- en nadelen van het gebruik van Fibase en RIO bij het onderzoek naar intergenerationele inkomensmobiliteit op een rij gezet. Bovendien komt ook nog de rol die het IPO kan spelen in het onderzoek aan de orde.

\section{Inkomensgegevens van het CBS}

\section{Regionaal Inkomensonderzoek (RIO)}

Het doel van het RIO is een beeld te geven van de verdeling van inkomens van personen of huishoudens naar landsdeel, provincie, corop-gebied, grootstedelijke agglomeratie, stadsgewest en gemeente. Het RIO is een longitudinaal steekproefonderzoek. Het oorspronkelijke panel, getrokken uit de bevolking van 15 jaar en ouder, dateert uit 1994. In de jaren daarna heeft als gevolg sterfte en emigratie telkens een bijtrekking uit 15-jarigen en immigranten plaatsgevonden. Het panel samen met de leden van hun huishoudens vormen de totale RIOsteekproef. In 2007 bestond de steekproef uit ruim 5,5 miljoen personen, circa een derde van de bevolking. Van de steekproefpersonen worden, in samenwerking met de Belastingsdienst, zowel demografische gegevens als fiscale inkomensgegevens verzameld. Daarnaast verstrekt de Informatie Beheer Groep gegevens over de studiefinanciering. Het CBS publiceert jaarlijks regionale inkomenscijfers op basis van het RIO. Deze cijfers hebben betrekking op inkomensgegevens van 1 januari tot en met 31 december. De meeste cijfers gaan over (personen in) particuliere huishoudens. Voor een uitgebreide beschrijving van het RIO wordt verwezen naar Ament en Kessels (2008).

2. Ook het zogenaamde Loonstructuuronderzoek van het CBS is vanwege de geringe steekproefomvang (0,6 procent van de bevolking) ongeschikt voor de koppeling met de onderwijscohortbestanden. 


\section{Fibase}

Door werkgevers en uitkeringsinstanties worden jaarlijks inkomensgegevens verstrekt aan de Belastingdienst. Het gaat hierbij om gegevens over het betaalde loon, de loonheffingen ingehouden door de werkgever en de hoogtes van uitkeringen in het kader van inkomensverzekeringen en sociale voorzieningen. Deze gegevens worden opgeslagen in de zogenoemde Fibase en worden door de Belastingdienst aan het CBS ter beschikking gesteld.

Inkomenspanelonderzoek (IPO)

Het IPO is vooral bestemd om gedetailleerde inkomenscijfers op landelijk niveau naar buiten te brengen (in tegenstelling tot het regionale niveau in het RIO). Het IPO heeft dezelfde (panel)steekproefopzet als het RIO. Het eerste jaar dat geschikt is voor het onderzoek naar intergenerationele inkomensmobiliteit is 1985 . Vanaf 1989 is het IPO jaarlijks beschikbaar. Het IPO- panel bestond in 2007 uit circa 90 duizend personen. De panelleden vormen samen met hun huishoudensleden de totale IPO-steekproef, die in 2007 uit ongeveer 260 duizend personen bestond. De inkomensgegevens zijn net als bij het RIO voornamelijk afkomstig van de Belastingdienst. Voor een uitgebreide beschrijving van het IPO wordt verwezen naar Van den Brakel en Moonen (2007).

\section{Inkomensbegrippen}

\section{Inkomen uit arbeid/eigen onderneming ('earnings')}

Het begrip 'earnings' omvat de inkomsten die personen verkrijgen door het verrichten van arbeid, en omvat daarom zowel inkomen uit arbeid en inkomen uit eigen onderneming. Inkomen uit arbeid bestaat uit loon en salaris (inclusief de werknemers- en werkgeversbijdrage in de premies voor de sociale verzekeringen), tantième, spaarloon en de beloning van arbeid die niet in dienstbetrekking is verricht. Ook de waarde van het privégebruik van de auto van de werkgever is hiertoe gerekend. Inkomen uit eigen onderneming is gelijk aan de fiscale winst vermeerderd met het bedrag van de vermogensaftrek en de investeringsaftrek ${ }^{3}$. Vermogensaftrek en investeringsaftrek worden als een belastingfaciliteit beschouwd en niet op het winstinkomen in mindering gebracht. De wegens meewerken aan de partner toegekende arbeidsbeloning wordt als arbeidsinkomen bij het inkomen van de partner geteld.

\section{Fiscaal inkomen}

Het totale inkomen (loon en uitkeringen) dat valt onder de voorheffing Loonbelasting.

\section{Besteedbaar huishoudensinkomen}

Het besteedbaar inkomen omvat loon, winst en inkomsten uit vermogen, vermeerderd met inkomensoverdrachten zoals AOW, WAO, bijstand en huurtoeslag (tezamen bruto-inkomen) en verminderd met onder meer loon-, inkomsten- en vermogensbelasting en premies inkomensverzekeringen en premies verplicht ziektekostenverzekeringen. ${ }^{4}$ Het huishoudensinkomen bestaat uit de som van inkomens van de afzonderlijke huishoudensleden.

3. Tot 2003 werd de investeringsaftrek wel op het winstinkomen in mindering gebracht

4. De ziektekostenpremies zijn pas vanaf 2003 in mindering gebracht. 


\section{Gestandaardiseerd inkomen}

Om inkomens van huishoudens van verschillende grootte en samenstelling vergelijkbaar te maken, wordt het besteedbaar huishoudensinkomen gestandaardiseerd. Hiervoor zijn equivalentiefactoren beschikbaar die afgestemd zijn op het aantal volwassenen en kinderen (naar leeftijd) in een huishouden. In de equivalentiefactor komen de schaalvoordelen tot uitdrukking die het gevolg zijn van het voeren van een gemeenschappelijke huishouding. Hierbij is de CBS-equivalentieschaal gebruikt, waarbij het eenpersoonshuishouden als standaardhuishouden is gekozen (CBS, 2004).

\section{Voor- en nadelen van Fibase, RIO en IPO}

Een belangrijk voordeel van de Fibase is dat in deze bestanden iedereen met fiscaal inkomen opgenomen is. Bij een koppeling met de onderwijscohorten zullen van het merendeel van de respondenten en van hun ouders inkomensgegevens beschikbaar zijn. Echter, de Fibase kent ook een aantal nadelen (zie tabel 1). Zo zijn er geen gegevens over zelfstandigen in beschikbaar. Ook bevat de Fibase maar één inkomensbegrip, namelijk het fiscaal inkomen. Het RIO daarentegen beschikt over een aantal extra inkomensbegrippen zoals het besteedbaar en het gestandaardiseerd inkomen. In de meeste internationale onderzoeken naar intergenerationele inkomensmobiliteit wordt het arbeidsinkomen ('earnings') gebruikt als indicator voor iemands financiële situatie. Indien Nederland vergeleken wordt met andere landen wat betreft de mate van de inkomensmobiliteit ligt derhalve het gebruik van dit inkomensbegrip het meest voor de hand. Echter, de levensstandaard van een persoon hangt niet alleen af van het eigen inkomen, maar ook van het inkomen van de andere gezinsleden. Daarom is het huishoudensinkomen een betere indicator voor de financiële situatie. Hierin komt immers tot uitdrukking wat een persoon of huishouden daadwerkelijk te besteden heeft. Nog een voordeel van het RIO is dat intergenerationele inkomensmobiliteit onderzocht kan worden voor specifieke groepen, zoals zelfstandigen en uitkeringsontvangers. Vooral bij zelfstandigen is een hoge mate aan inkomensoverdracht tussen generaties te verwachten. Een nadeel van het RIO ten opzichte van de Fibase is uiteraard dat het een steekproef is. Bij koppeling met de onderwijscohorten gaat ongeveer tweederde van de gegevens verloren, waardoor de analysemogelijkheden beduidend beperkter zijn.

Het IPO bevat veel verschillende inkomensbegrippen, waarbij de inkomensbron bekend is (bijv. loon uit arbeid), terwijl deze uit het RIO alleen geschat kan worden via de sociaaleconomische positie. Een ander voordeel van het IPO is dat het een langlopend panel is (1985-2008) waardoor inkomensgegevens bekend zijn van ouders en kinderen met een minimaal leeftijdverschil. ${ }^{5}$ Een beperking van het IPO is echter dat het een te kleine steekproef is voor koppeling met de schoolloopbaanonderzoeken, waardoor er met het IPO geen inzicht kan worden verkregen in de achterliggende factoren die de inkomensmobiliteit tussen generaties beïnvloeden.

5. Als ouders gemiddeld met hun dertigste kinderen krijgen is het leeftijdsverschil zeven jaar voor ouders en kinderen van wie het inkomen gemeten is in 1985 respectievelijk 2008. 
Tabel 1

Voor- en nadelen Fibase, RIO, IPO

\begin{tabular}{|c|c|c|}
\hline & VOORDELEN & NADELEN \\
\hline \multirow[t]{4}{*}{ FIBASE } & Integraal beschikbaar & Geen 'earnings', alleen fiscaal inkomen \\
\hline & & Geen zelfstandigen \\
\hline & & Geen huishoudinkomen \\
\hline & & $\begin{array}{l}\text { Indien de inkomensbron nodig is, is er veel } \\
\text { voorbereidend werk nodig om een } \\
\text { analysebestand klaar te maken (het } \\
\text { huidige bestand is alleen beschikbaar op } \\
\text { niveau van loonkaarten). Dit geldt ook voor } \\
\text { de variabele die het aantal weken waarin } \\
\text { het fiscaal inkomen is genoten voorstelt. }\end{array}$ \\
\hline \multirow[t]{4}{*}{ RIO } & $\begin{array}{l}\text { Naast fiscaal inkomen ook } \\
\text { huishoudinkomen beschikbaar } \\
\text { (besteedbaar, gestandaardiseerd) }\end{array}$ & $\begin{array}{l}\text { Grote steekproef, namelijk ca. een derde } \\
\text { van de bevolking }\end{array}$ \\
\hline & $\begin{array}{l}\text { Sociaaleconomische positie van } \\
\text { personen is beschikbaar: selectie } \\
\text { van zelfstandigen (en winst- } \\
\text { bedragen) en uitkeringsontvangers } \\
\text { is mogelijk }\end{array}$ & \\
\hline & $\begin{array}{l}\text { 'Earnings' te benaderen via } \\
\text { sociaaleconomische positie }\end{array}$ & \\
\hline & $\begin{array}{l}\text { Aantal weken waarin inkomen is } \\
\text { genoten is bekend }\end{array}$ & \\
\hline \multirow[t]{3}{*}{ IPO } & $\begin{array}{l}\text { Veel verschillende } \\
\text { inkomensbegrippen eenvoudig } \\
\text { beschikbaar, waaronder 'earnings' }\end{array}$ & $\begin{array}{l}\text { Zeer kleine steekproef, namelijk 1,6 } \\
\text { procent van de bevolking }\end{array}$ \\
\hline & $\begin{array}{l}\text { Aantal weken waarin inkomen is } \\
\text { genoten is bekend }\end{array}$ & \\
\hline & $\begin{array}{l}\text { Langlopend panel met } \\
\text { inkomensgegevens van ouders en } \\
\text { kinderen (1985-2008) }\end{array}$ & \\
\hline
\end{tabular}

\section{Aanbevelingen}

Voor de koppeling van inkomensgegevens met de schoolloopbaanonderzoeken van het CBS komen twee inkomensbestanden in aanmerking, namelijk het RIO en de Fibase. Omdat het RIO vergeleken met de Fibase veel rijker is aan inkomensinformatie en bovendien ook zelfstandigen (een groep met een hoge mate aan 
inkomensoverdracht) en uitkeringsontvangers bevat, gaat de voorkeur uit naar het gebruik van het RIO. Het RIO is beschikbaar vanaf $1995 .{ }^{6}$ De inkomensgegevens over de steekproefpersonen van de onderwijscohorten kunnen uit RIO $2007^{7}$ gehaald worden. De inkomensgegevens van hun ouders komen op z'n vroegst uit RIO 1995. Dit betekent dat de inkomenssituaties van ouders en kinderen niet op vergelijkbare momenten in hun levensloop gemeten wordt (zie ook paragraaf 3). De inkomensmobiliteit kan ten onrechte worden overschat wanneer deze momenten te ver uit elkaar liggen (Grawe, 2006). Om het effect hiervan in kaart te brengen, zullen simulaties uitgevoerd worden op basis van het IPO. Voor het uitsluitend schatten van inkomenselasticiteiten (waaronder de 'earnings elasticity') zonder dat er gekoppeld wordt met de schoolloopbaanonderzoeken, is het IPO het meest geschikt. Omdat het IPO het meest langlopende panel is (1985-2008) van de drie hier besproken inkomensbestanden, wordt het inkomen gemeten met een zo minimaal mogelijk leeftijdsverschil tussen ouders en kinderen.

Bij het onderzoek naar intergenerationele inkomensmobiliteit wordt doorgaans aanbevolen om gebruik te maken van een meerjarig inkomen (Solon, 1989). Voor het inkomen van de ouders zou dan gebruik gemaakt moeten worden van bijvoorbeeld RIO gegevens uit 1995, 1996 en eventueel 1997. Het verschil in leeftijd tussen ouders en kinderen wordt dan echter nog groter. Met het IPO kan nagegaan worden wat de invloed is van het gebruik van een meerjarig inkomen ten opzichte van een éénjarig inkomen. Eerder onderzoek naar intergenerationele inkomensmobiliteit heeft immers al aangetoond dat gebruik van een meerjarig inkomen invloed kan hebben op de uitkomsten (Van den Brakel en Moonen, 2009).

\section{Schoolloopbaanonderzoeken}

In Nederland is op basis van verschillende longitudinale cohortbestanden onderzoek verricht naar de invloed van sociale herkomst op de positie die personen verwerven op de arbeidsmarkt. In deze paragraaf wordt achtereenvolgens ingegaan op de verschillende schoolloopbaanbestandenonderzoeken, de informatie die hierin is opgenomen, en de mogelijkheden om te koppelen met de RIO-bestanden.

\section{Schoolloopbaanonderzoeken van het CBS}

In het schooljaar 1964/65 is gestart met het 'Van Jaar Tot Jaar'-cohort (Collaris \& Kropman, 1978; Diederen, 1991), dat tot ver in de jaren tachtig is gevolgd op de arbeidsmarkt. In 1977 is gestart met het SMVO-cohort, waarin de school- en beroepsloopbanen van ongeveer 37 duizend Nederlandse jongeren is vastgelegd (Meesters, 1992). In het schooljaar $1982 / 83$ startte een tweede schoolloopbaanonderzoek (SLVO) onder ongeveer 17 duizend leerlingen die toen in het laatste jaar van het basisonderwijs zaten (CBS, 1989). In het schooljaar 1989/90 is gestart met de eerste van een reeks van drie schoolloopbaanonderzoeken die nog jaarlijks geactualiseerd worden, namelijk de Voortgezet Onderwijs Cohort Leerlingen (VOCL) die worden uitgevoerd in opdracht van NWO. Het gaat om steekproeven van ongeveer 20 duizend leerlingen per cohort. Het tweede VOCL onderzoek startte in 1993/94 en het meest recente VOCL startte in het schooljaar 1999/00 (Hustinx et al., 2005a;

6. Feitelijk is in 1994 gestart met het RIO-panel, maar vanwege de beperkte inkomensgegevens die uit 1994 beschikbaar zijn, is het RIO 1994 niet geschikt voor het huidige onderzoek.

7. Afhankelijk van het tijdspad van het onderzoek kan mogelijk RIO 2008 gebruikt worden. 
Hustinx et al., 2005b; Kuyper et al., 2003). De onderwijscohorten bevatten naast informatie over de schoolloopbaan relevante achtergrondinformatie over de leerlingen en de ouders. Aan de hand hiervan kan worden bepaald in hoeverre het bereikte opleidingsniveau van leerlingen kan worden toegeschreven aan het milieu van herkomst en cognitief vermogen.

De doelstelling van de schoolloopbaanonderzoeken is in de afgelopen decennia wat verschoven, van een focus op sociologische vraagstukken over onderwijsongelijkheid naar een meer onderwijskundige focus. Daarnaast zijn ze ook in toenemende mate ingericht als monitor voor de effectiviteit van onderwijsbeleid. Mede hierdoor zijn de vragenlijsten voor deze onderzoeken op bepaalde punten afwijkend. In tabel 2 is weergegeven welke concepten relevant zijn voor het onderzoek naar intergenerationele inkomensmobiliteit en in welke mate deze terug te vinden zijn in de bij het CBS beschikbare schoolloopbaanonderzoeken.

\section{Tabel 2}

\section{Overzicht van schoolloopbaanonderzoeken}

\begin{tabular}{|l|c|c|c|c|c|c|}
\hline \hline Beschikbare gegevens & $\begin{array}{l}\text { Van Jaar } \\
\text { Tot Jaar }\end{array}$ & SMVO'77 & SLVO'82 & VOCL'89 & VOCL'93 & VOCL'99 \\
\hline \hline Eerste observatiejaar & $1964 / 65$ & $1977 / 78$ & $1982 / 83$ & $1989 / 90$ & $1993 / 94$ & $1999 / 00$ \\
\hline Rinpersoons-nummer & - & $+/-$ & + & + & + & + \\
\hline $\begin{array}{l}\text { Sociaal-demografische } \\
\text { kenmerken }\end{array}$ & $+/-$ & + & + & + & + & + \\
\hline $\begin{array}{l}\text { Onderwijsloopbaan } \\
\text { Cognitieve competenties }\end{array}$ & + & + & + & + & + & + \\
\hline $\begin{array}{l}\text { Sociale herkomst en } \\
\text { menselijk kapitaal }\end{array}$ & - & + & + & + & + & + \\
\hline $\begin{array}{l}\text { Cultureel kapitaal } \\
\text { Sociaal kapitaal }\end{array}$ & - & - & $+/-$ & $+/-$ & ++ & + \\
\hline \hline
\end{tabular}

Het databestand 'Van Jaar Tot Jaar' valt af vanwege het ontbreken van het zogeheten Rinpersoonsnummer. Hierdoor is geen koppeling mogelijk met registerdata van het CBS. Sociaaldemografische informatie (leeftijd, geslacht, etnische herkomst, gezinssamenstelling en dergelijke) is standaard aanwezig in de databestanden zelf, maar kan ook geactualiseerd worden via de GBA-bestanden van het CBS. In alle cohorten is de onderwijsloopbaan van de respondenten volledig in kaart gebracht. Dat betekent dat voor elk opeenvolgend jaar bekend is in welk onderwijs type en in welk leerjaar de betreffende respondent zit. Cognitieve competenties in de vorm van toetsen, intelligentie en schooladvies zijn in alle cohorten vanaf het SMVO1977 aanwezig. Vanaf VOCL'89 is daarnaast nog meer informatie beschikbaar, namelijk prestatiemotivatie en schoolbeleving. Indicatoren over sociale herkomst en het menselijk kapitaal in het gezin (beroep en opleiding van beide ouders) zijn in alle cohorten aanwezig. Indicatoren van cultureel en sociaal kapitaal zijn weliswaar op kleine schaal aanwezig in de cohorten 1982 en 1989, maar niet (goed) onderling vergelijkbaar. In VOCL'93 echter is er een uitgebreide vraagstelling met betrekking tot deze concepten. De eveneens uitgebreide vraagstelling hierover in VOCL'89 is vaak weer niet vergelijkbaar met die van cohort $1993 .^{8}$

8. Zie de Appendix voor een uitgebreid overzicht van de variabelen in het VOCL'89. 


\section{Koppeling met inkomensgegevens}

Uitgaande van een koppeling met de inkomensgegevens in de RIO-bestanden, ligt het voor de hand om gebruik te maken van het VOCL'89, en daarnaast van SLVO'82 en VOCL'93. Tabel 3 geeft inzicht in de leeftijd van de kinderen in 2008 en de leeftijd van de ouders in 1995 (het eerste meetjaar van het RIO). Uit analyses is gebleken dat de ouders in alle cohorten gemiddeld 30 jaar oud waren bij de geboorte van hun kind, waardoor deze leeftijd als aanname is genomen bij de berekening van de leeftijden van ouders en kinderen.

\section{Tabel 3}

Leeftijden kinderen en ouders in de VOCL- en RIO-bestanden onder de aanname dat ouders de kinderen hebben gekregen op 30-jarige leeftijd

\begin{tabular}{|l|l|l|l|l|}
\hline \multicolumn{2}{|c|}{ Kinderen } & \multicolumn{2}{c|}{ Ouders (+30*) } \\
\hline Cohort & Geboortejaar & $\begin{array}{l}\text { Leeftijd in } \\
2008\end{array}$ & $\begin{array}{l}\text { Gem. leeftijd in } \\
2008\end{array}$ & $\begin{array}{l}\text { Gem. leeftijd } \\
\text { RIO 1995 }\end{array}$ \\
\hline SLVO'82 & 1971 & 37 jr. & 67 jr. & 54 jr. \\
\hline VOCL'89 & 1977 & 31 jr. & 61 jr. & 48 jr. \\
\hline VOCL'93 & 1981 & 27 jr. & 57 jr. & 44 jr. \\
\hline & & & & \\
\hline
\end{tabular}

Uit de tabel komt naar voren dat het databestand van VOCL'93 voor ons doel minder geschikt is. De leeftijd van de respondenten uit dit bestand is 27 jaar in 2008. Dat betekent dat de inkomensontwikkeling zich nog voor een belangrijk deel moet uitkristalliseren. Met name voor de hoogopgeleide respondenten zal er sprake zijn van een onderschatting van het inkomen, hetgeen zich vertaalt in een hogere inkomensmobiliteit. De leeftijd van de respondenten uit SLVO'82 is eigenlijk min of meer ideaal (37 jaar), maar een mogelijk nadeel hier is dat de gemiddelde leeftijd waarop het inkomen van de ouders wordt vastgesteld aan de hoge kant is, namelijk 54 jaar. Voor het databestand van VOCL'89 geldt eigenlijk het omgekeerde: de gemiddelde leeftijd waarop het inkomen van de ouders kan worden waargenomen is goed (48 jaar), terwijl de gemiddelde leeftijd waarop het inkomen van de respondenten wordt vastgesteld wat aan de lage kant is, namelijk 31 jaar.

\section{Aanbevelingen}

Voor het hoofdonderzoek stellen we voor om van zowel SLVO'82 als VOCL'89 gebruik te maken. Dit biedt de mogelijkheid voor diverse robuustheidscontroles. Enerzijds kan gekeken worden of de beide databestanden vergelijkbare schattingen opleveren van inkomensmobiliteit. Daarnaast kan een gecombineerd bestand gemaakt worden waarbij gekeken wordt in hoeverre de schatting van inkomensmobiliteit gevoelig is voor verschillende leeftijdsselecties van de ouders.

\section{Conclusies}

Uit dit vooronderzoek is naar voren gekomen dat het mogelijk is om voor Nederland de intergenerationele inkomensmobiliteit te analyseren, en daarbij conclusies te trekken over welke mechanismen verantwoordelijk zijn voor de overdracht van de inkomensverdeling. Er is gebleken dat het onderzoek voor Nederland zich tot op heden langs twee lijnen heeft voltrokken. Het stratificatieonderzoek is sterk in het beschrijven van hoe de 
hulpbronnen in het gezin (menselijk kapitaal, economisch kapitaal, sociaal kapitaal, cultureel kapitaal) bijdragen aan het bereikte opleidingsniveau of de bereikte sociale status van de kinderen. Het ontbreekt hierin echter aan directe metingen van de inkomensmobiliteit tussen generaties. In het economisch onderzoek daarentegen wordt de intergenerationele inkomensmobiliteit doorgaans wel vastgesteld maar is er minder zicht op de mechanismen waarlangs deze overdracht plaatsvindt.

Het vooronderzoek heeft laten zien dat voor de inkomensgegevens het beste de RIO-bestanden gebruikt kunnen worden. Het RIO is vergeleken met de Fibase veel rijker aan inkomensinformatie en bevat bovendien ook zelfstandigen (een groep met een hoge mate aan inkomensoverdracht) en uitkeringsontvangers. Voor het hoofdonderzoek wordt voorgesteld om de RIO-bestanden te koppelen met de schoolloopbaanbestanden SLVO'82 en VOCL'89. De koppeling tussen RIO en deze bestanden voldoet het beste aan de diverse criteria betreffende de koppelmogelijkheden tussen de bestanden, de leeftijden van ouders en kinderen in de waarnemingsjaren, en de beschikbaarheid van verschillende verklarende variabelen.

Daarnaast kan gebruik gemaakt worden van het IPO om beter zicht te krijgen op de gevolgen van de beperkingen in de RIO- en schoolloopbaanbestanden. Het IPO kan weliswaar vanwege de geringe steekproefomvang niet gebruikt worden om te koppelen met de schoolloopbaanbestanden, maar er kunnen met het IPO wel een aantal zinvolle analyses worden gedaan. Ten eerste wordt in internationaal vergelijkend onderzoek meestal de 'earnings elasticity' geschat. Uit het IPO zijn de precieze arbeidsinkomsten bekend, terwijl deze uit het RIO alleen benaderd kunnen worden via de sociaaleconomische positie. Het effect van deze benadering op de schatting van de 'earnings elasticity' uit het RIO kan met het IPO in kaart gebracht worden. Daarnaast hebben we betoogd dat andere inkomensbegrippen te prefereren zijn boven 'earnings' om inkomensmobiliteit te schatten. Het IPO biedt de mogelijkheid om de verschillende 'elasticities' onderling zuiver te vergelijken. Ten tweede worden bij de koppeling van RIO- en schoolloopbaanbestanden de inkomenssituaties van ouders en kinderen niet op exact dezelfde momenten in hun levensloop gemeten (zie ook paragraaf 3). Om het effect hiervan in kaart te brengen, kunnen simulaties uitgevoerd worden op basis van het IPO. Ten derde kan met het IPO worden nagegaan worden wat de invloed is van het gebruik van een meerjarig inkomen ten opzichte van een éénjarig inkomen. Eerder onderzoek naar intergenerationele inkomensmobiliteit heeft immers al aangetoond dat gebruik van een meerjarig inkomen invloed kan hebben op de uitkomsten (Van den Brakel en Moonen, 2009). Dit is van belang omdat het inkomen van de ouders en kinderen in de gekoppelde bestanden in slechts één jaar wordt gemeten.

Het doel van de hierboven beschreven koppelingen en analyses is om minimaal één publicatie in een vooraanstaand internationaal wetenschappelijk tijdschrift te realiseren. Het gebruik van uitstekende inkomensgegevens uit het RIO in combinatie met gegevens over de diverse hulpbronnen in het gezin (menselijk kapitaal, economisch kapitaal, sociaal kapitaal, cultureel kapitaal) uit de schoolloopbaanonderzoeken biedt ons inziens veel publicatiemogelijkheden. Het onderzoek zal gebruik maken van wereldwijd unieke data met betrekking tot bijvoorbeeld het onderwijsondersteunend gedrag van ouders bij hun kinderen en de gevolgen daarvan voor de positie op de inkomensladder van de tweede ten opzichte van de eerste generatie.

Wat betreft de uitvoering en de planning is in gezamenlijk overleg tussen ROA en CBS geconstateerd dat het onderzoek uitstekend kan worden uitgevoerd in het kader van de samenwerkingsrelatie die beide instituten hebben. Wel wordt vanwege de planning van het CBS en het buitenlands verblijf van één van de onderzoekers van het ROA voorgesteld om de opleverdatum van het hoofdonderzoek enigszins te verschuiven, namelijk naar 1 maart 2011. Het weergegeven budget in de offerte van 25 november 2009 blijft echter wel van toepassing. Het 
ROA blijft voor het Ministerie van SZW eindverantwoordelijke in de oplevering van een Engelstalig onderzoekspaper.

\section{Literatuur}

Ament, P. en W. Kessels (2008), Regionaal inkomensonderzoek, uitgebreide onderzoeksbeschrijving, Centraal Bureau voor de Statistiek, Den Haag/Heerlen.

Brakel, M. van den, en L. Moonen (2007), Procesbeschrijving van het Inkomenspanelonderzoek, Centraal Bureau voor de Statistiek, Den Haag/Heerlen.

Brakel, M. van den, en L. Moonen (2009), Is armoede erfelijk? Sociaaleconomische trends, $2^{\mathrm{e}}$ kwartaal 2009, Centraal Bureau voor de Statistiek, Den Haag/Heerlen.

Büchner, C., W. Smits en R. van der Velden (2008), De invloed van onderwijs en gezinssituatie op arbeidsmarktsucces, Dynamiek in de sociale statistiek, CBS, Voorburg, pp. 87-101.

CBS (1989), Schoolloopbaan en herkomst van leerlingen in het voortgezet onderwijs. Cohort 1982 , Heerlen/Voorburg.

CBS (2004), Equivalentiefactoren 1995-2000, Centraal Bureau voor de Statistiek, Voorburg/Heerlen.

Collaris, J.W.M. en J.A. Kropman (1978), Van Jaar tot Jaar; een tweede fase: de wijze waarop secundair dagonderwijs doorlopen is, de eerste keuze na het verlaten daarvan, ITS, Nijmegen.

Cörvers, F. (2000a), Inkomensmobiliteit tussen generaties: laagste inkomensklassen weinig mobiel, Index: feiten en cijfers over onze samenleving, Vol 7, No. 7, pp. 30-31.

Cörvers, F. (2000b), Inkomensmobiliteit tussen huishoudens met lage inkomens van generatie op generatie, Armoedemonitor 2000, SCP/CBS, Den Haag, pp. 93-103.

Cörvers, J.G.F. (2000c), Als je voor een dubbeltje geboren bent..., Jaarboek Welvaartsverdeling 2000, CBS, Voorburg/Heerlen, pp. 63-66.

Cörvers, F. en I. de Loo (2001), Inkomensmobiliteit tussen generaties, Economisch Statistische Berichten, Vol. 86, pp. 264-266.

Cörvers, F. (2004), Income mobility of successive generations, in SCP/CBS, The poor side of the Netherlands, Results from the Dutch 'Poverty Monitor' 1997-2003, The Hague, pp. 120-124. 
Diederen, J. (1991), Loopbaan tussen 25 en 35 jaar; Van Jaar tot Jaar, vierde fase: over de effecten van geslacht, milieu van herkomst, schoolprestaties, belangstelling en gevolgd onderwijs op beroepsloopbaan en levensloop, ITS, Nijmegen.

Grawe, N.D. (2006), Lifecycle bias in estimates of intergenerational earnings persistence, Labour economics, Vol. 13, No. 5, pp. 551-570.

Hustinx, P.W.J., H. Kuyper, M.P.C. Van Der Werf en D.H. Zijsling (2005a), Beschrijving leerlingbestanden VOCL'89, Groningen, GION.

Hustinx, P.W.J., H. Kuyper, M.P.C. Van Der Werf en D.H. Zijsling (2005b), Beschrijving leerlingbestanden VOCL'93, Groningen, GION.

Kuyper, H., Lubbers, M.J. \& Werf, M.P.C. van der (2003). VOCL'99-1: Technisch rapport, Groningen, GION.

Meesters, M.J. (1992), Loopbanen in het onderwijs en op de arbeidsmarkt, ITS, Nijmegen.

OECD (2010), A Family Affair: Intergenerational Social Mobility across OECD countries, in: Going for Growth, Chapter 5, pp. 181-198, Paris.

Solon, G. (1989), Biases in the estimation of intergenerational earnings correlations, Review of Economics and Statistics, Vol. 71, No. 1, pp. 172-174.

Traag, T., J. van der Valk, R. van der Velden en R. de Vries (2006), Dertigers op de arbeidsmarkt, ROA-R2006/2, Universiteit Maastricht. 


\section{Appendix}

\begin{tabular}{|c|c|c|}
\hline & Bron & VOCL89 \\
\hline Steekproefomvang & & 19.524 \\
\hline Periode & & $1989-2009$ \\
\hline \multicolumn{3}{|l|}{ Sociaaldemografische informatie } \\
\hline $\begin{array}{l}\text { Rinpersoonsnummer (versleuteld } \\
\text { sofinummer) }\end{array}$ & & $x$ \\
\hline Geboortedatum & $\begin{array}{l}\text { Deze gegevens worden allen gekoppeld uit de Gemeentelijke } \\
\text { Basisadministratie. Gegevens over de woonplaats van de respondent } \\
\text { kunnen daardoor voor ieder peilmoment worden vastgesteld. } \\
\text { Alle informatie over de persoon zelf die afkomstig is uit de GBA, is } \\
\text { eveneens koppelbaar voor de ouders en de broers en zussen. De } \\
\text { informatie over de huishoudenssamenstelling in het eerste leerjaar is } \\
\text { ook rechtstreeks bevraagd bij de ouders. }\end{array}$ & $x$ \\
\hline Geslacht & & $x$ \\
\hline Geboorteland & & $x$ \\
\hline Aantal jaren in Nederland & & $x$ \\
\hline Nationaliteit & & $x$ \\
\hline Etnische herkomst & & $x$ \\
\hline Woonplaats & & $x$ \\
\hline Huishoudenssamenstelling & & $x$ \\
\hline Burgerlijke staat & & $x$ \\
\hline $\begin{array}{l}\text { Rinpersoonsnummer broers en } \\
\text { zussen }\end{array}$ & & $x$ \\
\hline $\begin{array}{l}\text { Rinpersoonsnummer vader en } \\
\text { moeder }\end{array}$ & & $x$ \\
\hline Land waar basisschool bezocht & Oudervragenlijst leerjaar 1 & $x$ \\
\hline Maand start basisonderwijs & Oudervragenlijst leerjaar 1 & $\mathrm{x}$ \\
\hline Jaar start basisonderwijs & Oudervragenlijst leerjaar 1 & $x$ \\
\hline Leeftijd start basisonderwijs & $\begin{array}{l}\text { De vragen over de basisschoolperiode zijn voor VOCL'89 gesteld in } \\
\text { de leerlingvragenlijst in het eerste leerjaar. Voor VOCL'93 zijn ze } \\
\text { gesteld aan de ouders in het derde leerjaar. }\end{array}$ & $x$ \\
\hline
\end{tabular}




\begin{tabular}{|c|c|c|}
\hline Verblijfsduur basisonderwijs & & $x$ \\
\hline \multicolumn{3}{|l|}{ Cognitieve competenties } \\
\hline Schooladvies & Leerlingvragenlijst leerjaar 1 & $x$ \\
\hline Totaalscore entreetoets & $\begin{array}{l}\text { De entreetoets is klassikaal afgenomen in de eerste maanden van } \\
\text { resp. } 1990 \text { en 1994.De entreetoets is ontworpen door het CITO en is } \\
\text { voor beide schoolloopbaanonderzoeken ongewijzigd afgenomen. De } \\
\text { toets kan gezien worden als een verkorte versie van de CITO } \\
\text { afsluitingstoets basisonderwijs. } \\
\text { In het derde leerjaar zijn de entreetoetsen nogmaals afgenomen. } \\
\text { Hieraan is voor VOCl'93 een toetsonderdeel voor Algemene } \\
\text { Vaardigheden toegevoegd. }\end{array}$ & $x$ \\
\hline Taalscore entreetoets & & $\mathrm{x}$ \\
\hline Rekenscore entreetoets & & $x$ \\
\hline $\begin{array}{l}\text { Informatieverwerkingsscore } \\
\text { entreetoets }\end{array}$ & & $x$ \\
\hline PSB3 Subtest redeneren & $\begin{array}{l}\text { De intelligentietoetsen zijn klassikaal afgenomen in de eerste } \\
\text { maanden van resp. } 1990 \text { en 1994. In het derde leerjaar zijn beide } \\
\text { toetsen nogmaals, in ietwat aangepaste vorm, afgenomen, maar } \\
\text { uitsluitend voor het VOCL'89. } \\
\text { De totaalscore van beide toetsen geeft hooguit een indicatie van de } \\
\text { verschillen in non-verbale intelligentie binnen de groep leerlingen. Het } \\
\text { is geen betrouwbare meting van intelligentie. }\end{array}$ & $x$ \\
\hline PSB8 Subtest abstraheren & & $x$ \\
\hline Non-verbale intelligentie & & $\underline{x}$ \\
\hline Schoolbeleving & $\begin{array}{l}\text { De begrippen schoolbeleving en prestatiemotivatie zijn beide in zowel } \\
\text { leerjaar } 1 \text { als leerjaar } 3 \text { gemeten op basis van in totaal } 15 \text { items. } \\
\text { Daarnaast is er voor VOCL' } 93 \text { in het eerste leerjaar een additionele } \\
\text { vragenlijst afgenomen met } 21 \text { items die expliciet bedoeld waren om } \\
\text { prestatiemotivatie te meten (PMTK). Pas later is geconcludeerd dat } \\
\text { op basis van de vragenlijst van } 15 \text { items beide begrippen voldoende } \\
\text { betrouwbaar gemeten werden. }\end{array}$ & $x$ \\
\hline Prestatiemotivatie & & $x$ \\
\hline
\end{tabular}




\begin{tabular}{|c|c|c|}
\hline \multicolumn{2}{|l|}{ Onderwijsloopbaan } & \\
\hline Brincode school op 01/09/tttt & $\begin{array}{l}\text { Van oorsprong werden de jaarlijkse gegevens over de } \\
\text { onderwijsloopbaan van leerlingen ofwel via de school (PAPI) dan wel } \\
\text { via de leerling zelf (CATI) verzameld. Met de komst van het } \\
\text { onderwijsnummer is deze vorm van primaire waarneming steeds } \\
\text { verder naar de achtergrond verdwenen. Daar waar informatie kan } \\
\text { worden verkregen door koppeling met onderwijsregistraties, wordt } \\
\text { voor dit alternatief gekozen. Leerlingen die niet in het } \\
\text { onderwijsnummerbestand van dat jaar te traceren zijn, worden alsnog } \\
\text { met een telefonische vragenlijst benaderd. }\end{array}$ & $x$ \\
\hline \multicolumn{3}{|l|}{ Onderwijspositie op 01/09/tttt } \\
\hline Examenresultaat schooljaar tttt/tttt+1 & & $x$ \\
\hline Vertrekcode schooljaar tttt/tttt+1 & & $x$ \\
\hline Examenvakken schooljaar tttt/tttt+1 & & $x$ \\
\hline \multicolumn{3}{|l|}{ Schoolkenmerken } \\
\hline Denominatie van de school & $\begin{array}{l}\text { Informatie afkomstig uit het steekproefkader van de VOCL- } \\
\text { onderzoeken. Hiernaast kan, door koppeling via het Brinnummer, } \\
\text { additionele informatie toegevoegd worden over de school. }\end{array}$ & $x$ \\
\hline Onderwijsvoorrangsgebied & & $x$ \\
\hline \multicolumn{3}{|l|}{ Sociale herkomst } \\
\hline Huishoudenssamenstelling & Oudervragenlijst leerjaar 1 & \\
\hline Aantal kinderen in het huishouden & Oudervragenlijst leerjaar 1 & $x$ \\
\hline $\begin{array}{l}\text { Aantal oudere kinderen in het } \\
\text { huishouden }\end{array}$ & Oudervragenlijst leerjaar 1 & $x$ \\
\hline Hoogst behaald onderwijsniveau & $\begin{array}{l}\text { Gevraagd aan de invullende ouder en de partner (als aanwezig) in de } \\
\text { oudervragenlijst leerjaar 1. Deze informatie is in VOCL' } 93 \text { uitgebreider } \\
\text { gevraagd dan in VOCL'89, maar is wel in vergelijkbare schalen uit te } \\
\text { drukken. }\end{array}$ & $x$ \\
\hline Hoogst gevolgd onderwijsniveau & & $x$ \\
\hline Beroepsniveau & $\begin{array}{l}\text { In beide onderzoeken is in de oudervragenlijst in het eerste jaar } \\
\text { vragen gesteld over de arbeidsmarktstatus van de invullende ouder } \\
\text { en de partner (als aanwezig). Hieruit is het beroepsniveau afgeleid. } \\
\text { Deze schaling is voor beide onderzoeken vergelijkbaar. De } \\
\text { onderliggende vragen verschillen voor beide onderzoeken. }\end{array}$ & $x$ \\
\hline Nederlands spreken met het kind & $\begin{array}{l}\text { In beide onderzoeken is gevraagd naar de taal waarin de ouder met } \\
\text { het kind spreken. In VOCL' } 89 \text { is gevraagd of de ouder doorgaans } \\
\text { Nederlands spreekt met het kind. In VOCL' } 93 \text { is aan beide ouders } \\
\text { gevraagd welke taal de ouder met het kind spreekt. Het is niet bekend } \\
\text { of dit vergelijkbare resultaten oplevert. }\end{array}$ & $x$ \\
\hline
\end{tabular}




\begin{tabular}{|c|c|c|}
\hline \multirow[t]{5}{*}{ Cultureel kapitaal } & $\begin{array}{l}\text { In de oudervragenlijst leerjaar } 1 \text { zijn voor VOCL' } 89 \text { vragen gesteld } \\
\text { over culturele participatie en leesgedrag van de ouders. Voor } \\
\text { VOCL' } 93 \text { zijn er in leerjaar } 3 \text { eveneens vragen gesteld over kijk- en } \\
\text { leesgedrag (van zowel ouders als de leerling), maar deze zijn niet } \\
\text { rechtstreeks vergelijkbaar met de items zoals die hier benoemd zijn. }\end{array}$ & $x$ \\
\hline & & $x$ \\
\hline & & $x$ \\
\hline & & $x$ \\
\hline & & $x$ \\
\hline $\begin{array}{l}\text { Onderwijsondersteunend gedrag } \\
\text { ouders }\end{array}$ & $\begin{array}{l}\text { In de oudervragenlijst in het eerste leerjaar is voor de VOCL' } 89 \\
\text { populatie gevraagd hoe vaak het voor kwam dat ouders met hun kind } \\
\text { spraken over gebeurtenissen op school, met het knd sprak over } \\
\text { prestaties op school, het kind aanspoorde harder te werken etc. Deze } \\
\text { concepten zijn tezamen te beschouwen als onderwijsondersteunend } \\
\text { gedrag van de ouders. In VOCL'93 zijn soortgelijke vragen gesteld in } \\
\text { de oudervragenlijst in leerjaar } 3 \text {, maar deze zijn niet identiek aan de } \\
\text { vragen gesteld in het kader van VOCL' } 89 \text { en het is niet duidelijk of ze } \\
\text { tot vergelijkbare resultaten leiden. }\end{array}$ & $x$ \\
\hline Sociaal kapitaal & $\begin{array}{l}\text { In de oudervragenlijst van het derde leerjaar van VOCL'93 is aan } \\
\text { ouders gevraagd naar de mate waarin zij met familie, collega's en } \\
\text { vrienden praten over de opvoeding en de opleiding van hun kind. }\end{array}$ & \\
\hline Sociaal netwerk & $\begin{array}{l}\text { In de oudervragenlijst van het derde leerjaar van VOCL'93 is aan } \\
\text { ouders gevraagd naar het sociale netwerk van hun kind. Het ging dan } \\
\text { om zaken als het aantal klasgenoten/vrienden waarvan men de } \\
\text { ouders kende, of men met die ouders gesproken had etc. }\end{array}$ & \\
\hline Sekse-rolopvatting & $\begin{array}{l}\text { In de oudervragenlijst van het derde leerjaar van VOCL'93 is aan } \\
\text { ouders gevraagd naar de denkwijze over de taakverdeling tussen } \\
\text { mannen en vrouwen. Deze items zijn samengevat in één schaal. }\end{array}$ & \\
\hline Opvoedingsstijl & $\begin{array}{l}\text { In de oudervragenlijst van het derde leerjaar van VOCL'93 is aan } \\
\text { ouders gevraagd naar de autonomie van het kind ten opzichte van de } \\
\text { ouders. Deze items zijn samengevat in één schaal. }\end{array}$ & \\
\hline
\end{tabular}

